\title{
Urban Governance in Africa: An Overview
}

\author{
Warren Smit
}

\begin{abstract}
Africa is urbanising rapidly and is facing enormous urban challenges, such as the growth of slums and increasing inequality. Secondary cities, with their smaller economies and less capacitated local governments compared to primary cities, face particularly severe challenges. However, responsibility for key urban governance issues is often fragmented amongst large numbers of government stakeholders with limited capacities and conflicting interests. Key urban governance stakeholders therefore need to be brought together in collaborative processes to jointly develop and implement new strategies that are based on a broader range of interests and meet a broader range of needs. In order to be able to do this, understanding actual urban governance processes, which are essentially about how different actors interact to make and operationalise decisions, is vitally important. This chapter highlights the diversity of actors involved in urban governance in Africa and the complexity of urban governance processes, with Kisumu, a secondary city in Kenya, used as an example. Key actors in urban governance in African cities include all levels of government, political parties, traditional leaders, private sector organisations and informal business organisations (such as traders' organisations), international agencies and civil society organisations. The basic objects of urban governance can include a wide range of issues, such as land use management, the provision of basic services, ensuring access/mobility and ensuring public health and safety. The diversity of governance actors and of agendas complicates addressing urban issues, but can also be seen as an opportunity for leveraging additional skills and resources through collaborative urban governance processes that bring different stakeholders together to develop and implement more holistic and inclusive strategies.
\end{abstract}

\section{Introduction}

Africa is the most rapidly urbanising region of the world and has immense urban challenges, such as growing slums and growing poverty and inequality, combined with weak government capacity (UN-Habitat, 2014). Urban Africa,

(C) WARREN SMIT, 2018 | DOI:10.1163/9789004387942_004

This is an open access chapter distributed under the terms of the prevailing CC-BY-NC License at the time of publication. 
though, also has enormous opportunities and potential for innovation. Key to effectively tackling urban challenges in Africa is an understanding of urban governance processes and how they can be enhanced and strengthened. This chapter attempts to highlight the diversity of actors involved in urban governance in African cities, and the complexity of urban governance processes.

It should be noted that Africa is a vast and diverse continent, and there are enormous international and intra-national differences in urbanisation dynamics and governance conditions. Nevertheless, there are certain key urban governance trends that are widespread in Africa. Drawing on a review of the literature on governance in Africa and on personal experience of working in a number of cities across the continent, I review some of the key issues relating to African urban governance, showing how responsibility for key urban governance issues is often fragmented amongst large numbers of government stakeholders with limited capacities and conflicting interests, and that, in order to overcome these challenges, governance stakeholders need to be brought together in collaborative processes to jointly develop and implement new strategies that are based on a broader range of interests and meet a broader range of needs. As secondary cities in Africa face particularly severe challenges - given their weaker economies and weaker local governments compared to primary cities-I particularly focus on the experiences of secondary cities, using Kisumu (the third-largest city in Kenya) as an example. This chapter is partially based on a review of 101 peer-reviewed articles relating to urban governance in Africa (see Smit, 2016) and partially on a stakeholder workshop held in Kisumu in July 2015 and the analysis of interviews with a range of governance stakeholders in Kisumu conducted in June 2016.

First, I briefly review some of the key challenges facing African cities. I then discuss different conceptions of governance and define my working definition of governance as the complex ways through which groups and individuals engage with each other to, in practice, make and operationalise decisions. Using Kisumu as an illustrative example, I then discuss the key governance actors found in most African cities and examine four particular arenas of urban governance: land use management, the provision of basic services, transport/mobility, and food safety. Although certain aspects of these governance processes function adequately, there are also many cases of fragmentation and a lack of coordination between urban governance actors. Finally, I discuss the possibility of overcoming these problems through developing collaborative governance processes that bring different stakeholders together to develop and implement more holistic and inclusive strategies. 
The urban population of Africa has been growing rapidly, from an estimated 237 million in 1995 to an estimated 472 million in 2015, an average growth rate of 3.44 per cent per year (UN-Habitat, 2016). Although megacities like Lagos dominate the literature on African cities, in fact, the fastest growing urban centres are the smaller cities with less than one million inhabitants, which accounted for 62 per cent of the urban population in Africa in 2015 (UN-Habitat, 2016).

Unlike urbanisation in many other parts of the world, urban population growth in most of Africa has generally not been accompanied by a commensurate increase in formal employment, resulting in growing urban poverty and increased urban vulnerability (Bryceson and Potts, 2006; Fox, 2012). The capacity of government bodies to plan for and manage urban growth in Africa is generally relatively weak (Myers, 2011). The net result of rapid urbanisation and inadequate capacity for planning or managing cities is the rise of inequality, the increasing prevalence of informality, and increased health risks. The growth of 'slums' is the most tangible manifestation of these issues. In 2014, an estimated $5^{6}$ per cent of sub-Saharan Africa's urban population lived in informal settlements or other types of slum - that is to say, areas lacking adequate housing and services. The number of households living in slums in subSaharan Africa has been growing steadily_from an estimated 111 million in 1995 to 201 million in 2015 (UN-Habitat, 2016).

Secondary cities in Africa face particularly severe challenges. The concept of 'secondary cities' emerged from the concept of 'primate cities' proposed by Jefferson (1939). Whereas primate cities are the large cities that dominate the economic and political life of their countries, secondary cities are essentially non-primate cities, ranging from small cities of about 100,000 people to national second cities with populations in the millions (Rondinelli, 1983). It has recently been recognised that secondary cities play a key role in urbanisation processes (for example, Roberts, 2014). Secondary cities generally have weaker urban economies than primate cities, and thus 'suffer from weaker institutional and financial bases', but, simultaneously, 'rates of demographic growth are often higher in secondary compared with primate cities' (UN-Habitat, 2016, 172-173). The net result is that secondary cities are typically characterised by 'chronic inequality of opportunities, widespread poverty, inadequate capital investments in public goods, and lack of pro-poor social programmes' (UNHabitat, 2016, 173). Kisumu in Kenya is a typical example of a secondary city. It was founded in 1901 by the British as a railway terminus port (Anyumba, 1995), 
and now is the third-largest city in Kenya, with a population of about 500,000 people, compared with more than 3 million people in Kenya's primate city, Nairobi (AFD, 2013). As with many African countries, the national economy is highly concentrated in the primate city, with few manufacturing activities in secondary cities (Otiso, 2005). The smaller revenue base means a smaller and less capacitated local government. As is typical of many secondary cities in Africa, Kisumu is strongly linked with a specific ethnic identity (Luo), whereas the primate city of Nairobi is more cosmopolitan. Intersections between ethnic identity and political parties have generally meant that parties in opposition to the national government have generally predominated in Kisumu, frequently resulting in conflict, such as was the case during the elections of October 2017 (Allison, 2017). All these factors have combined to make urban governance challenges in Kisumu particularly complex.

Urban governance is both one of the key challenges facing African cities and a potential lever for helping African cities become more equitable, with a better quality of life for residents. 'Governance' is also a contested concept that can mean many things; in the next section, I discuss the concept and what seems to be a useful definition.

\section{3}

\section{The Concept of Governance}

Governance can be defined in various ways. The term governance became widely used in the 1990s to refer to the shifting patterns of governing linked to the 'hollowing out' of the state associated with neo-liberalisation (Rhodes, 1997; Stoker, 1998). The term governance was seen as signifying 'a change in the meaning of government, referring to a new process of governing; or a changed condition of ordered rule; or the new method by which society is governed' (Rhodes, 1997, 652-653). Whereas 'government' was seen as being characterised by hierarchies and clear separations between state and society (Kjær , 2011), governance at the local level is seen as being characterised by a blurring of public-private boundaries, the rise of networks, and an increased role for actors other than the local government in the attainment of public goals (Pierre, 2005).

The term 'good governance' became especially linked with the World Bank, as a normative 'development paradigm' (Obeng-Odoom, 2017). The World Bank's first mention of 'good governance' was in the foreword to the 1989 World Bank Study Sub-Saharan Africa-from Crisis to Sustainable Growth (World Bank, 1989), and the concept was further fleshed out in two subsequent reports, Governance and Development (World Bank, 1992) and Governance, The 
World Bank's Experience (World Bank, 1994). The World Bank's conception of governance, which largely focused on efficiency and accountability, has been criticised for being 'a mainly administrative and managerialist interpretation of good governance' (UN-Habitat, 2016, 10), for being too depoliticised, and for being associated with elements of neo-liberal ideology, such as the need to promote conditions favourable for international businesses (Doornbos, 2001; Olivier de Sardan, 2011; Pearce, 2003).

United Nations (UN) agencies also instituted campaigns for good governance, but with a greater emphasis on democratic practice and human and civil rights (UN-Habitat, 2009). UNDP defined governance more broadly, as 'the mechanisms, processes and institutions through which citizens and groups articulate their interests, exercise their legal rights, meet their obligations and mediate their differences' (UNDP, 1997, 2-3). The two key aspects of this definition are as follows: 'Governance as a concept recognizes that power exists inside and outside the formal authority and institutions of government. [...] Second, governance emphasizes "process". It recognizes that decisions are made based on complex relationships between many actors with different priorities' (UN-Habitat, 2002, 12-13). Building on this, UN-Habitat launched its Global Campaign on Urban Governance (Taylor, 2000; UN-Habitat, 2002). UNHabitat has defined urban governance as 'the sum of the many ways individuals and institutions, public and private, plan and manage the common affairs of the city [...] It includes formal institutions as well as informal arrangements' (UN-Habitat, 2002, 14). UN-Habitat's good urban governance campaign focused on the outcomes of governance, seeing good urban governance as resulting in ensuring that all residents have 'access to the necessities of urban life, including adequate shelter, security of tenure, safe water, sanitation, a clean environment, health, education and nutrition, employment and public safety and mobility' (UN-Habitat, 2002, 14).

Many scholars have used the UN conception of governance, or similar definitions, in an analytical way, to understand actual processes of governing and the complex ways in which different governance actors engage with each other (through formal and informal processes and in relationships ranging from cooperation to deep conflict) to make and operationalise decisions (for example, Bakker et al., 2008; Smit, 2016). In reality, non-government stakeholders have always played a key role in governing, and using governance as an analytical concept can help shed light on how decisions are actually made and implemented and can assist in identifying opportunities for intervention. As Koechlin $(2016,7)$ notes, using the concept of governance in this non-normative way 'opens up a window to identify and understand complex forms of interaction and co-ordination between different actors'. 
One of the key characteristics of using a governance lens is the recognition that there is a wide range of actors involved in governance, such as various government organisations, civil society organisations-for example, nongovernmental organisations ( $\mathrm{NGOS}$ ) and community groups - and the private sector (Devas, 2001). Using a governance lens is essentially about understanding these actors and the relationships between them. Inextricably intertwined with these processes are power and politics. Power can be conceived of as being distributed amongst these different actors and 'exercised from innumerable points' (Foucault, 1998 [1976], 94) by individuals such as planners, policy analysts and researchers, and politicians (Richardson, 1996). Power is not evenly distributed, however, as there are particular 'centres' or 'nodes' with concentrations of power (Lindell, 2008). These 'governance nodes' are groups of decision makers where knowledge, capacity and resources are mobilised to manage the course of events (Johnston and Shearing, 2003; Shearing and Wood, 2003). As Watson (2009) notes, different nodes can have very different ways of viewing the world, or 'conflicting rationalities', which can make engagement extremely difficult. In particular, there is a vast divide between an 'increasingly informalised and marginalised population and techno-managerial and marketised systems of government' (Watson, 2009, 2272).

These governance nodes impact on cities and towns through a range of 'formal' and 'informal' decision-making and regulatory processes. ${ }^{1}$ As Devas (2004b) notes, informal governance processes are, in practice, often more important than formal governance processes. Closely linked to these governance processes, of course, is politics; as Rakodi $(2001,216)$ notes, these issues of power, resources, accountability and legitimacy are 'the stuff of politics'.

\section{Urban Governance Actors in African Cities}

The essence of using a governance lens is recognising that there is a wide range of actors involved in urban governance, with very different interests and agendas. Below, I discuss the main types of urban governance actors in African cities: government, traditional leaders, the private sector, international agencies, and civil society.

1 As discussed in the introduction to this special issue, formality/informality should be regarded as a continuum rather than a dichotomy, but I use the terms to refer to the respective ends of the continuum. 


\subsection{Government}

All levels of government can play an important role in governing urban areas. Policymaking and the division of national revenue typically occur at a national level, and subnational levels of governments (states, provinces, counties or districts) often also perform key functions. Although the allocation of functions between different levels of government can vary enormously from country to country, local government bodies generally play a key role in urban governance.

Much of Africa did not have a tradition of strong local government in the colonial or early post-independence eras. However, from the 1980 s onwards there was a shift towards decentralisation in Africa as governments and international agencies decided that improved urban management, decentralisation, and local democracy were interlinked (most notably, in the World Bank's 'good governance' agenda). The implementation of decentralisation in Africa has, however, been very uneven and partial, and has in some cases been reversed (Andrews and Schroeder, 2003; Smit and Pieterse, 2014; UN-Habitat, 2008). Although there are potentially advantages to decentralisation if it is undertaken carefully (with capacity development and resource allocation accompanying the transferral of responsibilities to lower levels of government), it has been argued by some scholars that the rushed and partial decentralisation of public authority in Africa has often resulted in local governments that are 'weak, disorganized, inadequately trained and staffed, and often underresourced relative to the new range of responsibilities they are expected to take on' (Meagher, 2011, 51). In addition, the role of local government is often further complicated by the key position it plays in the patronage system of political parties (Obeng-Odoom, 2017) and by the widespread phenomenon of African cities often being the bases of political parties in opposition to national governments led by parties with a largely rural support base (Resnick, 2011).

Simultaneously with increased decentralisation (and also linked to the 'good governance' agenda of the World Bank), there has been a shift in recent decades in the way local governments in Africa operate, towards privatisation and partnerships (Myers, 2005; Nunan and Satterthwaite, 2001; Olivier de Sardan, 2011). Privatisation of service delivery often disadvantages the urban poor, who are unable to pay for adequate levels of service provision. This is exacerbated by local governments usually having 'inherited a collection of repressive bylaws, and planning and building standards, which are unsuited to the needs and ability to pay of the poor' (Devas, 2001, 404).

The case of Kisumu reflects the typical complexity found in urban governance in Africa. Kisumu Municipal Council used to be a relatively autonomous local government body, located within Nyanza Province. Subsequent to 
the 2010 Constitution of Kenya, there was major restructuring of subnational government in Kenya, resulting in counties becoming the main subnational level of government. There is still a municipal administration (Kisumu City), but although it is meant to have a Municipal Board (according to the 2011 Urban Areas and Cities Act) the Governor of Kisumu County has not officially established this board (as is generally also the case in other counties in Kenya). Kisumu City essentially functions as an agency of Kisumu County, with all Kisumu City officials employed by Kisumu County. There are also a number of independent agencies that operate in the area, such as the Kisumu Water and Sewerage Company (KIWASCO). In addition, many national ministries also play a direct role in Kisumu; for example, the National Ministry of Land and Housing allocates land within the city area.

Closely intertwined with these various levels of government are political parties. Although there has been a rapid spread of multiparty democracy in Africa in recent decades, the political landscape tends to be dominated by clientelist political parties (i.e. those which focus on providing benefits to their constituents), which analysis suggests are less likely to improve the quality of public services than are programmatic political parties (parties with coherent and consistent positions on policy issues) (World Bank, 2017). As is very common in African cities, Kisumu is (and has almost always been since independence) the base of a political party in opposition to the ruling party at the national level—the Orange Democratic Movement (ODM) party, which became part of the Coalition for Reforms and Democracy (CORD). Members of this party hold most elected positions in the Kisumu area, including that of county governor and those of members of parliament and members of the county assembly. There has been frequent violent political conflict in Kisumu, most notably the violence following the 2007 General Election (for example, see Harneit-Sievers and Peters, 2008).

\subsection{Traditional Leaders}

A typical characteristic of urban governance in Africa is that traditional leaders often play an important role in governance-for example, with regard to land allocation in peri-urban areas. Traditional leaders can be more accessible to residents than elected politicians are, although they can also be 'unresponsive, corrupt and interested mainly in maintaining power and patronage' (Devas, 2004a, 118). Olivier de Sardan (2011) notes that their only real accountability is to higher levels of government.

In Kisumu, outside of the historical core of the city, traditional leaders play an officially recognised role in governance. 'Locations' are headed by Chiefs, 'sub-locations' are headed by Assistant Chiefs and 'sub-units' are headed by 
one or two village elders (Omedo et al., 2014). Chiefs, Assistant Chiefs and village elders all play an important role in the governance of Kisumu-for example, in government health-promotion campaigns (Omedo et al., 2014).

\subsection{Private Sector}

Large private sector organisations, such as property development or food production companies, can play an important role in urban governance in African cities. In some cases, 'their actions can be damaging to the poor, forcing them off land they occupy and preventing informal traders from operating' (Devas, 2001, 400). Informal business organisations can also play an important role in urban governance, governing marketplaces for example, but they usually have less influence on government decision-making than do big, private sector companies (Brown et al., 2010). For example, a study of informal business organisations in Nigeria highlights their limitations in affecting formal decisionmaking, noting that 'small entrepreneurs pay their local government taxes and even some state-level taxes, but they continue to receive little in the way of basic services in return' (Meagher, 2011, 68).

In Kisumu, big property development companies are playing a major role in the urban transformation of the city, through investment in a number of large development projects, mainly shopping malls. One company, which is investing in a mixed-use project linked to a shopping mall, has the stated ambition of turning Kisumu into another Dubai, for the East Africa region (Matete, 2016). The Chamber of Commerce also plays a prominent role in Kisumu, leading, for example, attempts to relocate street traders away from the main shopping street of the city. Informal trader organisations play an important role in managing all the marketplaces in Kisumu (for example, by ensuring that these markets are cleaned).

\subsection{International Agencies}

Multilateral agencies, development banks, and international donor agencies play a large and important role in African cities. Most global aid and loans to Africa are linked to the 'good governance' agenda and the promotion of decentralisation and democratisation (Dietrich and Wright, 2015). In Kisumu, the World Bank and the Agence Française de Développement (AFD) are particularly active funders and have invested vast amounts in infrastructure, including in the new motorway system that encircles the city. Particularly notable is the Integrated Strategic Urban Development Plan (ISUD-Plan), which is funded by AFD and has a budget of 40 million euros. It seeks to prepare for the city's future through a range of strategies, including planning Kisumu's expansion, upgrading informal settlements, refurbishing and building new markets, and 
by developing strategies for capital investment in the city (AFD, 2013). There are also a number of international NGOs active in Kisumu on a range of issues, such as Plan International (which works on children's rights).

\subsection{Civil Society}

There is a vast range of civil society associations who, in practice, play a key role in urban governance in Africa. These include ethnicity-based networks, home-town associations, youth associations, savings groups, and funeral groups (Devas, 2001; Olivier de Sardan, 2011; Tostensen et al., 2001). These organisations often, in practice, perform roles undertaken by the state in cities in the global North, such as providing basic services, allocating land, ensuring safety, providing social security nets, and so on. In addition, many Westernstyle community associations have been set up by international development agencies, often with a focus on 'wells, grain mills, credit, seeds, market gardening, etc.' (Olivier de Sardan, 2011, 25). Various types of religious associations (for example, charismatic movements and Islamic brotherhoods) also play an important role in urban governance in Africa, particularly with regards to humanitarian interventions such as providing food (Olivier de Sardan, 2011). NGOs can also be important 'in enabling communities to organize and articulate demands' (Devas, 2001, 401).

As is the case with most African cities, Kisumu has a large number of civil society organisations, most of which belong to a federation called the Civil Society Organisation Network. There is a particular concentration of NGOs in Kisumu, with an estimated goo based in the city - this figure includes a number of international NGOS, but mainly consists of local organisations (Prince, 2013). There are a large number of HIV/AIDS organisations with offices in Kisu$\mathrm{mu}$, as the surrounding region has an HIV prevalence rate that is double the national average (Camlin et al., 2013).

Governance does not occur for its own sake; there are particular objects, tangible or intangible, that are governed. Governance can be considered as 'collective practices addressing societal problems' (Förster, 2016, 211). In an urban context these 'problems' are the collective issues that have always impacted on the lives of residents whenever large groups of people live in close proximity to each other, and include how to govern who can do what where, how to ensure access to water and sanitation and solid waste disposal, and how to ensure there is a well-functioning transport system. The most basic object of urban 
governance is land allocation and land use management, which essentially is about who can do what where. The second most basic object of urban governance is the provision and management of basic infrastructure/services, such as water, sanitation, and waste management. A third key object of governance can be considered as the movement/accessibility system, which is essentially about how people and goods can get around from one part of the settlement to another-at its most basic, this will consist of footpaths and roads, while at a higher level there would be buses, trains, and so on. In most settlements there are formal or informal organisations that attempt to govern these issues; for example, in informal settlements there are typically residents' associations that allocate land and ensure some basic level of service provision and maintenance of footpaths (Smit, 2006).

Beyond these basic and widespread objects of urban governance, found in most contexts, there are also many other possible objects of urban governance, such as ensuring good health and well-being, ensuring safety from crime and violence, disaster risk management, education, social/cultural development, economic development, environmental management, and so on. In this chapter, I discuss the three basic objects of urban governance, and also look at food safety as an example of another object of urban governance.

\subsection{Land Use Management}

African countries generally have multiple land administration systems: formal systems of deed registries with freehold and leasehold title; officially recognised customary tenure systems; and informal, extra-legal tenure in informal settlements. Areas with formal tenure generally have zoning schemes and building regulations enforced by the state, whereas these are generally not enforced in customary or informal tenure areas. African cities are often characterised by 'unregulated peri-urban land development' (Kombe, 2005, 113). The ability of local government to control such sprawl is often limited by peri-urban areas being in customary ownership and under the authority of traditional leaders (for example, Gough, 1999).

A major land use management issue in many African cities is urban agriculture. While some scholars see urban agriculture as having an important role to play in poverty reduction and food security (e.g. Lee-Smith, 2010), most African national and local governments are intolerant of urban agriculture, seeing it as incompatible with their 'modernist' visions of what cities should look like (Kuusaana and Eledi, 2015; Simatele and Binns, 2008; Tong, 2010), viewing it as a rural activity 'whose practice within the city boundaries is inappropriate and detracts from the modern image of the city' (Simatele and Binns, 2008, 2). In African cities experiencing steep economic decline, however, there has been 
a rapid increase in levels of participation in urban agriculture, and organisations of urban farmers can play an important role in promoting and supporting urban agriculture (Schmidt et al., 2015). In Dar es Salaam for example, the activities of urban farmers' associations include 'joint production on communally held property and serving as a loan or finance agency for their members' (Schmidt et al., 2015, 158).

Another important aspect of land use management is the governance of retail, which essentially is about who can sell what where (and when). Much of the retail sector in most African cities can be classified as being at the 'informal' end of the formality/informality continuum. There are usually a wide variety of different types of informal food retail outlets, such as large, traditional marketplaces (which might have thousands of traders), various types of informal shops and kiosks, and street traders. Urban governance can impact on informal traders in various ways, including through processes for allocating trading space and through the provision of infrastructure and services, such as water, electricity and refuse removal.

Marketplaces are a particularly important element of urban food systems in Africa and are an important site of urban governance. Market associations generally play an important role in managing marketplaces in Africa (King, 2006; Lyon, 2003; Porter et al., 2007). In Maputo, for example, 'the market committees provide infrastructure (water, toilets, etc.), maintenance and security services, and organise cleaning in their respective markets [...] The committees also act as the principal regulators in the markets' (Lindell, 2008, 1889). Trader associations govern marketplaces using a range of techniques-such as surveillance, peer pressure and control of physical space (Lyon, 2003) - and can sometimes also influence the plans of local government (King, 2006). Local governments also usually play a role in managing marketplaces, partially because trader fees can be a significant source of local government revenue (King, 2006). As most local governments lack adequate power to plan, regulate and provide infrastructure and services, this role is often limited to collecting fees (Meagher, 2011). Whereas traders in marketplaces have some protection as a result of the large number of traders and some form of official recognition, street traders are much more vulnerable. There are frequently waves of evictions of street traders to 'clear the streets' - for example, when there is a change of political power or when a major event is about to take place (Devas, 2001; Hansen, 2004; King, 2006).

Over time, the nature of food retail in African cities has been changing, with increased growth in 'formal' retail outlets. In the past two decades there has been rapid growth in supermarkets in Africa, with largely negative impacts on 
the food security of the urban poor (Crush and Frayne, 2011; Reardon et al., 2003, 2004, 2007; Weatherspoon and Reardon, 2003). For example, between 1995 and 2012, Shoprite Checkers, a South African supermarket chain, opened 131 supermarkets in 16 different African countries outside of South Africa (Battersby and Peyton, 2014). Currently, the roll-out of supermarkets is being driven by the private sector; Crush and Frayne (2011, 806) note that there is an 'absence of regulatory controls on supermarket expansion in urban markets' in Africa (for example, as to where they are located, how big they are, whether they are accessible to pedestrians, whether they offer trading space for informal traders, and so on).

Kisumu is typical of African cities in that it has a low-density, 'formal' historic core (mainly consisting of land leased from the state on 99-year leaseholds), where building and regulations are quite tightly enforced, surrounded by a zone of dense, informal areas (many of which are been upgraded) and 'ancestral land' areas (now technically under freehold ownership) where planning and building regulations are much less enforced (Anyumba, 1995). Kisumu is also typical of state views of urban agriculture in African cities. An estimated $5^{\circ}$ per cent of Kisumu's residents are engaged in urban/peri-urban agriculture, even though it was, until recently, technically illegal in terms of public health and water legislation. With the introduction of the Urban Areas and Cities Act of 2011 urban agriculture became legal. In terms of retail, Kisumu has 30 marketplaces, with Kibuye market being the biggest. Kisumu City collects fees from these traders on a daily or monthly basis - at the Jubilee Market, for example, the fee is 30 Kenyan Shillings per day for traders outside the market (collected every day) and 350-60o Kenyan Shillings per month for stalls inside the market (paid monthly to the City) — but provides little in return. Market associations play an important role in managing marketplaces. In some markets, such as Jubilee market, traders' associations collect additional fees to provide services, including sanitation and cleaning. A number of markets are scheduled for redevelopment (through the provision of new multi-storey buildings) as part of the Kisumu Urban Project, but all these projects have been delayed. In Kisumu, street traders are in a precarious position. For example, the street traders who occupy the pavements of Jaramogi Oginga Odinga Avenue (the main street of Kisumu) are constantly at risk of being relocated due to perceptions that they obstruct the pavements and negatively impact on formal businesses along the street. In the past two decades the number of supermarkets in Kisumu has grown to 20, many of them the anchor tenants of shopping malls. There has been virtually no local government control over the location/design of supermarkets or what they sell. 


\subsection{Provision and Management of Basic Infrastructure/Services}

Providing basic services such as water, sanitation and waste management is usually a key purpose of urban governance. In most cases, this is the main official role of local government, but in general only a small proportion of African urban residents are served by state-provided services-as noted earlier, $5^{6}$ per cent of Africa's urban population live in unserviced areas (UN-Habitat. 2016), and even many serviced areas have stand-alone infrastructure such as VIP toilets and boreholes rather than networked infrastructure. This gap in infrastructure provision has (partially) been filled by the provision of services in particular areas by community groups and NGOS.

Kisumu reflects the typical complexity of service provision in African cities, particularly water provision. The Kisumu Water and Sewerage Company (KIWASCO) is a privatised utility company that was set up in 2003 to replace the water and sewerage department of the former Kisumu Municipal Council. It is supervised by Lake Victoria South Water Services Board, one of seven regional water boards in Kenya. As the formal water and sewerage network was limited to only the area of the former colonial town, in order to roll out water provision to peri-urban areas KIWASCO has relied upon a network of subcontractors who in turn sell water to connected customers and to water kiosk operators, the latter selling on to unconnected customers (Schwartz and Sanga, 2010). Although this approach has been successful in extending the provision of water supply, the net result is a very uneven pattern of access to water, with the extent of piped, private connections and yard taps ranging from 97.6 per cent of households in a high-income area (Milimani) to only 2.8 per cent in Migosi Estate (Wagah et al., 2010).

Solid waste management is a particular area of concern, with the Kachok dumpsite in the centre of Kisumu unable to cope with all the waste generated (Munala and Moirongo, 2011; Sibanda et al., 2017). City officials estimate that only between 20 per cent and 35 per cent of solid waste is collected (either directly by the City or by private collectors who sell their services to companies and institutions), leaving about $65^{-80}$ per cent (of which most is organic waste) uncollected (Sibanda et al., 2017). There are a number of informal waste pickers in Kisumu, who play an important role in the recycling of waste.

A number of NGOs and community groups are actively involved in the provision of water, sanitation, energy and solid waste management (e.g. Practical Action and SANA International), but these are generally small, ad hoc projects.

\subsection{Urban Transport Systems}

The key elements of urban transport systems are the provision and maintenance of roads, managing traffic, and ensuring the roadworthiness of vehicles. 
In general, urban transport infrastructure in African cities is inadequate. A study of 14 cities in Africa found that 'to a greater or lesser extent in each of the cities, the networks of paved roads and associated traffic control facilities are deficient' (Kumar and Barrett, 2008, 37). The stock of vehicles is also largely inadequate: 'widespread dilapidation is apparent, as basic safety standards with regard to lighting, tires, and brakes are openly flouted. Systems and procedures for routine vehicle inspections are clearly failing, while petty corruption among police officers means that no action is taken on the road' (Kumar and Barrett, 2008, 37). The net result is that many African cities are choked with traffic congestion.

Kisumu used to be a rail centre and important harbour, but now its main transport links are roads. A number of agencies are involved in providing and maintaining roads in Kisumu (Kenya National Highways Authority, Kenya Urban Roads Authority, Kenya Rural Roads Authority, etc.), with lots of overlap and duplication. It is estimated that only about 30 per cent of the existing road network is being maintained. Although not very pedestrian friendly, Kisumu's transport system generally works well, with a wide range of affordable transport options, such as minibus taxis, tuk-tuks, boda-bodas (motorcycle taxis) and bicycle taxis. A Bus Rapid Transit (B RT) system is planned for Kisumu, even though evidence suggests that BRT systems are only feasible in larger cities (Hidalgo and Gutiérrez, 2013).

\subsection{Food Safety}

The main determinants of food safety are 'the procedures and standards and regulations (or lack of) for food production, processing, and packaging' (Ericksen, 2008, 240). Many food-safety regulations need to be enforced at a national level, but at the city scale there needs to be local-level enforcementfor example, in the form of regular visits by health inspectors. While regulating and enforcing food production, processing, distribution and retail in the formal sector can be relatively straightforward if there is sufficient capacity in place, addressing food safety in the informal sector is probably the main food-safety challenge faced at the local level (Cambaza dos Muchangos et al., 2015).

Street foods are a particular concern. Numerous studies have confirmed that street food can have a high risk of contamination (for example, Roesel and Grace, 2015). Typical issues include inadequate access to water and sanitation, inadequate refuse removal, and exposure to flies, which can all result in the contamination of food.

Some, but not all, local governments are involved in enforcing standards of hygiene amongst informal traders (Muyanja et al., 2011). Even where local 
government does attempt to enforce health standards, this enforcement is often only partial. For example, in Abeokuta, Nigeria, food vendors are required to obtain an annual certificate from health authorities, but a survey found that only 31 per cent of vendors had these (Omemu and Aderoju, 2008).

The Kisumu City Health Department is meant to ensure food safety, but is understaffed (they say they ideally need 30 health inspectors, but only have 14). The department runs a clinic for food handlers, carrying out screening and vaccinations for typhoid, hepatitis B and TB. The health inspectors check 'hot spots' once per week, but there is a lack of equipment with which to undertake proper tests (such as testing milk).

The net result of the wide range of governance actors with very different agendas found in urban governance processes in Africa is that, as Lindell $(2008,1896)$ notes with regard to the governance of marketplaces in Maputo, 'governance appears to lack any semblance of coherence and to be fragmented, disjointed and split by deep antagonisms. The key actors continuously challenge each other's legitimacy to "govern". The governance of most issues is characterised by fragmentation and a lack of coordination between governance actors; in the case of government actors, the ability to enforce regulations is usually quite limited. Skills and resources seem to be more thinly spread and diffused than is the case than in the global North, meaning that one or two urban governance actors acting in isolation on their own are seldom able to address many key urban challenges. As a result, key problems such as inadequate infrastructure in marketplaces, traffic congestion and inadequate waste disposal systems are not addressed, and the problems persist and grow over time.

Although this diversity of actors can be seen as a problem, it can, however, also be seen as an opportunity for mobilising additional skills and resources with which to address challenges in African cities. Following this view, there have been repeated calls for collaborative governance-bringing 'multiple stakeholders together in common forums with public agencies to engage in consensus-orientated decision-making' (Ansell and Gash, 2008, 543) —and for the 'co-production' of contextually appropriate projects and policies by a range of urban governance actors (Polk, 2015). In the words of Harrison $(2006,320)$, we need to recognise the existence of multiple rationalities and search for 'the in-between spaces, the interstices, where different conceptions of the city, and of planning and rationality, have intermingled and have produced hybrid logics and practices'. 
There have been some attempts at this in Kisumu, initially through the multistakeholder Kisumu Action Team (КАT). KAT initially only represented a narrow range of interests, but subsequently included broader representation-for example, of the informal traders in Kisumu (Onyango and Obera, 2015). KAT used 'interdisciplinary, cross-sector and policy approaches [...] to solve some of the urban planning and development issues in the city, drawing on inputs from various stakeholders' (Onyango and Obera, 2015, 93). This was a conflictridden process, but resulted in the raising of substantial funds for an ambitious range of physical upgrading projects in Kisumu, such as the redevelopment of the marketplaces. KAT then transformed into the Kisumu Local Interaction Platform (KLIP), a consortium of Kisumu City, Kisumu County, the Civil Society Coalition, the Chamber of Commerce and the two local universities (Maseno University and the Jaramogi Oginga Odinga University of Science and Technology) that undertakes collaborative research and implementation to develop Kisumu (Polk, 2016). In this way, the limited skills and resources available for dealing with urban problems in a secondary city like Kisumu have been pooled together and used to leverage more resources, and different interests have been brought together to develop strategies that are more holistic, inclusive and sustainable.

Access to information and data is crucial for effective collaborative governance. Although many governments are wary of making data accessible to the public (World Bank, 2017), this is an essential precondition for civil society and other stakeholders to engage with government bodies in collaborative governance.

In order to be able to collaboratively design and implement interventions to improve the quality of life of urban residents, we need to better understand existing, complex urban governance processes and the competing interests of urban governance actors. Through establishing multi-stakeholder forums such as KAT and KLIP, and through ensuring that all stakeholders have access to information and relevant data, different interest groups can be brought together to successfully collaborate on planning for and managing cities, and more appropriate local strategies and projects can be developed and implemented. Collaborative governance can be messy and conflictual, but only through facilitating engagement and collaboration between different urban governance actors can urban challenges in Africa be effectively addressed.

\section{References}

AFD (Agence Français de Développement) (2013) Kisumu: ISUD-Plan: Part 1. Integrated Strategic Urban Development Plan: Understanding Kisumu, (Kisumu: AFD). 
Allison, S. (2017) 'Kisumu Boycotted the Kenyan Elections, Though They Didn't Have Much Choice', Mail and Guardian, 26 October, https://mg.co.za/article/2017-10-26in-kisumu-the-election-that-wasnt (accessed on 20 April 2018).

Andrews, M. and L. Schroeder (2003) 'Sectoral Decentralisation and Intergovernmental Arrangements in Africa', Public Administration and Development, 23(1), pp. 29-40, DOI: $10.1002 /$ pad.257.

Ansell, C. and A. Gash (2008) 'Collaborative Governance in Theory and Practice', Journal of Public Administration Research and Theory, 18(4), pp. 543-571, DOI: 10.1093/ jopart/mumo32

Anyumba, G. (1995) Kisumu Town: History of the Built Form, Planning and Environment: 1890-199o (Delft: Delft University Press).

Bakker, K., M. Kooy, N.E. Shofiani and E.-J. Martijn (2008) 'Governance Failure: Rethinking the Institutional Dimensions of Urban Water Supply to Poor Households', World Development, 36(10), pp. 1891-1915, DOI: 10.1016/j.worlddev.2007. 09.015 .

Battersby, J. and S. Peyton (2014) 'The Geography of Supermarkets in Cape Town: Supermarket Expansion and Food Access', Urban Forum, 25(2), pp. 153-164, DOI: 10.1007/s12132-014-9217-5.

Brown, A., M. Lyons and I. Dankoco (2010) 'Street Traders and the Emerging Spaces for Urban Voice and Citizenship in African Cities', Urban Studies, 47(3), pp. 666-683, DOI: $10.1177 / 0042098009351187$.

Bryceson, D. and D. Potts (eds.) (2006) African Urban Economies: Viability, Vitality or Vitiation? (London: Palgrave Macmillan).

Cambaza dos Muchangos, A.B., K. Roesel, C. McCrindle, H. Matusse, S. Hendrickx, K. Makita and D. Grace (2015) 'Informal markets in Mozambique Risky for Local Chicken', in K. Roesel and D. Grace (eds.), Food Safety and Informal Markets: Animal Products in Sub-Saharan Africa (Abingdon: Routledge), pp. 197-200.

Camlin, C.S., Z.A. Kwena and S.L. Dworkin (2013) 'Jaboya vs. Jakambi: Status, Negotiation, and HIV Risks among Female Migrants in "the Sex for Fish" Economy in Nyanza Province, Kenya', AIDS Education and Prevention, 25(3), pp. 216-231, DOI: 10.1521/aeap.2013.25.3.216.

Crush, J. and B. Frayne (2011) 'Supermarket Expansion and the Informal Food Economy in Southern African Cities: Implications for Urban Food Security', Journal of Southern African Studies, 37(4), pp. 781-807, DOI: 10.1080/03057070.2011 $.61753^{2}$.

Devas, N. (2004a) 'Urban Government: Capacity, Resources and Responsiveness' in N. Devas (ed.), Urban Governance, Voice and Poverty in the Developing world (London: Earthscan), pp. 95-122.

Devas, N. (2004b) 'Urban Poverty and Governance in an Era of Globalization, Decentralization and Democratization' in N. Devas (ed.), Urban Governance, Voice and Poverty in the Developing World (London: Earthscan), pp. 15-36. 
Devas, N. (2001) 'Does City Governance Matter for the Urban Poor?' International Planning Studies, 6(4), pp. 393-408, DOI: 10.1080/13563470120092395.

Dietrich, S. and J. Wright (2015) 'Foreign Aid Allocation Tactics and Democratic Change in Africa', The Journal of Politics, 77(1), pp. 216-234, DOI: 10.1086/678976.

Doornbos, M. (2001) 'Good Governance: The Rise and Decline of a Policy Metaphor?' The Journal of Development Studies, 37(6), pp. 93-108, DOI: 10.1080/713601084.

Ericksen, P.J. (2008) 'Conceptualizing Food Systems for Global Environmental Change Research', Global Environmental Change, 18(1), pp. 234-245, DOI: 10.1016/j. gloenvcha.2007.09.002.

Förster, T. (2016) 'The Formation of Governance: The Politics of Governance and Their Theoretical Dimensions', in L. Koechlin and T. Förster (eds.), The Politics of Governance: Actors and Articulations in Africa and Beyond (New York: Routledge), pp. 197-218.

Fox, S. (2012) 'Urbanization as a Global Historical Process: Theory and Evidence from sub-Saharan Africa', Population and Development Review, 38(2), pp. 285-310, DOI: 10.1111/j.1728-4457.2012.00493.x.

Foucault, M. (1998 [1976]) The Will to Knowledge: The History of Sexuality Volume 1, Translated by R. Hurley (London: Penguin).

Gough, K. (1999) 'The Changing Nature of Urban Governance in Peri-urban Accra, Ghana', Third World Planning Review, 21(4), pp. 393-410.

Hansen, K.T. (2004) 'Who Rules the Streets? The Politics of Vending Space in Lusaka' in K.T. Hansen and M. Vaa (eds.), Reconsidering Informality: Perspectives from Urban Africa (Uppsala: Nordic Africa Institute).

Harrison, P. (2006) 'On the Edge of Reason: Planning and Urban Futures in Africa', Urban Studies, 43(2), pp. 319-335, DOI: 10.1080/00420980500418368.

Harneit-Sievers, A. and R.-M. Peters (2008) 'Kenya's 2007 General Election and Its Aftershocks', Afrika Spectrum, 43(1), pp. 133-144, http://nbn-resolving.de/urn:nbn: de:0168-ssoar-35326o (accessed on 20 April 2018).

Hidalgo, D. and L. Gutiérrez (2013) 'BRT and BHLS around the World:Explosive Growth, Large Positive Impacts and Many Issues Outstanding', Research in Transportation Economics, 39(1), pp. 8-13, DOI: 10.1016/j.retrec.2012.05.018.

Jefferson, M. (1939) 'The Law of the Primate City', Geographical Review, 29(2), pp. 226 232. DOI: $10.2307 / 2155^{28}$.

Johnston, L. and C. Shearing (2003) Governing Security: Explorations in Policing and Justice (London: Routledge).

King, R. (2006) 'Fulcrum of the Urban Economy: Governance and Street Livelihoods in Kumasi, Ghana' in A. Brown (ed.), Contested Space: Street Trading, Public Space, and Livelihoods in Developing Cities (Rugby: ITDG Publishing), pp. 100-118.

Kjær, A.M. (2011) 'Rhodes' Contribution to Governance Theory: Praise, Criticism and the Future Governance Debate', Public Administration, 89(1), pp. 101-113. DOI: 10.1111/j.1467-9299.2011.01903.x. 
Koechlin, L. (2016) 'Introduction: The conceptual polysemy of governance', in L. Koechlin and T. Förster (eds.), The Politics of Governance: Actors and Articulations in Africa and Beyond (paperback edition; New York: Routledge), pp. 1-22.

Kombe, W.J. (2005) 'Land Use dynamics in Peri-urban areas and Their Implications on the Urban Growth and Form: The Case of Dar es Salaam, Tanzania', Habitat International, 29(1), pp. 113-135. DOI: 10.1016/So197-3975(03)ooo76-6.

Kumar, A. and F. Barrett (2008) Stuck in Traffic: Urban Transport in Africa (Washington, DC: World Bank).

Kuusaana, E.D. and J.A. Eledi (2015) 'As the City Grows, Where do the Farmers go? Understanding Peri-urbanization and Food Systems in Ghana-Evidence from the Tamale Metropolis', Urban Forum, 26(4), pp. 443-465. DOI: 10.1007/s12132-015-926o-x.

Lee-Smith, D. (2010) 'Cities Feeding People: An Update on Urban Agriculture in Equatorial Africa', Environment and Urbanization, 22(2), pp. 483-499, DOI: 10.1177/ 0956247810377383 .

Lindell, I. (2008) 'The Multiple Sites of Urban Governance: Insights from an African City', Urban Studies, 45(9), pp. 1879-1901, DOI: 10.1177/0042098008093382.

Lyon, F. (2003) 'Trader Associations and Urban Food Systems in Ghana: Institutionalist Approaches to Understanding Urban Collective Action', International Journal of Urban and Regional Research, 27(1), pp. 11-23. DOI: 10.1111/1468-2427.00428.

Matete, F. (2016) 'Mega City to Make Kisumu "like Dubai", The Star, 10 February, https://www.the-star.co.ke/news/2016/o2/10/mega-city-to-make-kisumu-like -dubai_c1291774 (accessed on 16 September 2017).

Meagher, K. (2011) 'Informal Economies and Urban Governance in Nigeria: Popular Empowerment or Political Exclusion?', African Studies Review, 54(2), pp. 47-72, DOI:10.1353/arw.2011.0026.

Munala, G. and B.O. Moirongo (2011) 'The Need for an Integrated Solid Waste Management in Kisumu, Kenya', Journal of Agriculture Science and Technology, 13(1), pp. $65-78$.

Muyanja, C., L. Nayiga, N. Brenda and G. Nasinyama (2011) 'Practices, Knowledge and Risk Factors of Street Food Vendors in Uganda', Food Control, 22(10), pp. 1551-1558. DOI: 10.1016/j.foodcont.2011.01.016.

Myers, G.A. (2011) African Cities: Alternative Visions of Urban Theory and Practice (London: Zed Books).

Myers, G.A. (2005) Disposable Cities: Garbage, Governance and Sustainable Development in Urban Africa (Aldershot: Ashgate).

Nunan, F. and D. Satterthwaite (2001) 'The Influence of Governance on the Provision of Urban Environmental Infrastructure and Services for Low-income Groups', International Planning Studies, 6(4), pp. 409-426, DOI: 10.1080/13563470120103365.

Obeng-Odoom, F. (2017) 'Urban Governance in Africa Today: Reframing, Experiences, and Lessons', Growth and Change, 48(1), pp. 4-21, DOI:10.1111/grow.12164. 
Olivier de Sardan, J.-P. (2011) 'The Eight Modes of Local Governance in West Africa'. IDS Bulletin, 42(2), pp. 22-31, DOI: 10.1111/j.1759-5436.2011.00208.x.

Omedo, M., M. Ogutu, A. Awiti, R. Musuva, G. Muchiri, S.P. Montgomery, W.E. Secor and P. Mwinzi. (2014) 'The Effect of a Health Communication Campaign on Compliance with Mass Drug Administration for Schistosomiasis Control in Western Kenya-The SCORE Project', American Journal of Tropical Medicine and Hygiene, 91(5), pp. 982-988, DOI: 10.4269/ajtmh.14-0136.

Omemu, A.M. and S.T. Aderoju (2008) 'Food Safety Knowledge and Practices of Street Food Vendors in the City of Abeokuta, Nigeria', Food Control, 19(4), pp. 396-402. DOI: 10.1016/j.foodcont.2007.04.021.

Onyango, G.M. and B.O. Obera (2015) 'Tracing Kisumu's Path in the Co-production of Knowledge for Urban Development', in M. Polk (ed.), Co-producing Knowledge for Sustainable Cities: Joining Forces for Change (Abingdon: Routledge), pp. 73-97.

Otiso, K.M. (2005) 'Kenya's Secondary Cities Growth Strategy at a Crossroads: Which Way Forward?' GeoJournal, 62(1), pp. 117-128. DOI: 10.1007/s10708-005-8180-z.

Pearce, K.C. (2003) 'Democracy and Development as Contested Terrain: The Discourse of the 'Good Governance' Agenda in Africa', Review of Communication, 3(1), pp. 28-30, DOI: $10.1080 / 1835859032000084151$.

Pierre, J. (2005) 'Comparative Urban Governance: Uncovering Complex Causalities', Urban Affairs Review, 40(4), pp. 446-462, DOI: 10.1177/1078087404273442.

Polk, M (2016) 'How to manage Complexity: Co-producing Knowledge for Urban Change', in Co-production in Action: Towards Realising Just Cities (Gothenburg: Mistra Urban Futures), pp. 32-45.

Polk, M. (ed.) (2015) Co-producing Knowledge for Sustainable Cities: Joining Forces for Change (Abingdon: Routledge).

Porter, G., F. Lyon and D. Potts (2007) 'Market Institutions and Urban Food Supply in West and Southern Africa: A Review', Progress in Development Studies, 7(2), pp. 115134, DOI: 10.1177/146499340600700203.

Prince, R. (2013) “Tarmacking” in the Millennium City: Spatial and Temporal Trajectories of Empowerment and Development in Kisumu, Kenya', Africa, 83(4), pp. 582605, DOI: $10.1017 /$ Sooo1972013000478.

Rakodi, C. (2001). 'Forget Planning, Put Politics First? Priorities for Urban Management in Developing Countries', International Journal of Applied Earth Observation and Geoinformation, 3(3), pp. 209-223, DOI:10.1016/So303-2434(01)85029-7.

Reardon, T., C.P. Timmer, C.B. Barrett and J. Berdegúe (2003) 'The Rise of Supermarkets in Africa, Asia, and Latin America', American Journal of Agricultural Economics, 85(5), pp. 1143-1146. DOI: 10.1111/j.0092-5853.2003.00520.x.

Reardon, T., P. Timmer and J. Berdegue (2004) 'The Rapid Rise of Supermarkets in Developing Countries: Induced Organizational, Institutional, and Technological 
Change in Agrifood Systems', Electronic Journal of Agricultural and Development Economics, 1(2), pp. 168-183.

Reardon, T., S. Henson and J. Berdegúe (2007) 'Proactive Fast-tracking' Diffusion of Supermarkets in Developing Countries: Implications for Market Institutions and Trade', Journal of Economic Geography, 7(4), pp. 399-431, DOI: 10.1093/jeg/lbmoo7.

Resnick, D. (2011) 'In the Shadow of the City: Africa's Urban Poor in Opposition Strongholds', The Journal of Modern African Studies, 49(1), pp. 141-166. DOI: 10.1017/ Soo22278X1000o686.

Rhodes, R.A.W. (1997) Understanding Governance: Policy Networks, Governance, Reflexivity and Accountability (Buckingham: Open University Press).

Richardson, T. (1996) 'Foucauldian Discourse: Power and Truth in Urban and Regional Policy Making', European Planning Studies, 4(3), pp. 279-292, DOI: 10.1080/ og654319608720346.

Roberts, B.H. (2014) Managing Systems of Secondary Cities: Policy Responses in International Development (Brussels: Cities Alliance/UNOPS).

Roesel, K. and D. Grace (eds.) (2015) Food Safety and Informal Markets: Animal Products in Sub-Saharan Africa (Abingdon: Routledge).

Rondinelli, D.A. (1983) 'Dynamics of Growth of Secondary Cities in Developing Countries', Geographical Review, 73(1), pp. 42-57. DOI: 10.2307/214394.

Schmidt, S., W. Magigi and B. Godfrey (2015) 'The Organization of Urban Agriculture: Farmer Associations and Urbanization in Tanzania', Cities, 42(Part B), pp. 153-159. DOI:10.1016/j.cities.2014.05.013.

Schwartz, K. and A. Sanga (2010) 'Partnerships between Utilities and Small-scale Providers: Delegated Management in Kisumu, Kenya', Physics and Chemistry of the Earth, Parts $A / B / C$, 35(13), pp. 765-771, DOI: 10.1016/j.pce.2010.07.003.

Shearing, C. and J. Wood (2003) 'Nodal Governance, Democracy, and the New "Denizens"', Journal of Law and Society, 30(3), pp. 400-419, DOI: 10.2307/1410537.

Sibanda, L.K., N. Obange and F.O. Awuor (2017) 'Challenges of Solid Waste Management in Kisumu, Kenya', Urban Forum, 28(4), pp. 387-402. DOI: 10.1007/s12132-017-9316-1.

Simatele, D.M. and T. Binns (2008) 'Motivation and Marginalization in African Urban Agriculture: The Case of Lusaka, Zambia', Urban Forum, 19(1), pp. 1-21, DOI: 10.1007/ S12132-008-9021-1.

Smit, W. (2016) 'Urban Governance and Urban Food Systems in Africa: Examining the Linkages', Cities, 58, pp. 80-86, DOI: 10.1016/j.cities.2016.05.001.

Smit, W. (2006) 'Understanding the Complexities of Informal Settlements: Insights from Cape Town', in M. Huchzermeyer and A. Karam (eds.), Informal Settlements: A Perpetual Challenge? (Cape Town: Juta), pp. 103-125.

Smit, W. and E. Pieterse (2014) 'Decentralisation and Institutional Reconfiguration in Urban Africa' in S. Parnell and E. Pieterse (eds.), Africa's Urban Revolution: Policy Pressures (London: Zed Books), pp. 148-166. 
Stoker, G. (1998) 'Governance as Theory: Five Propositions', International Social Science Journal, 50(155), pp. 17-28, DOI: 10.1111/1468-2451.00106.

Taylor, P. (2000) 'Institutional Profile: UNCHS (Habitat) - The Global Campaign for Good Urban Governance'. Environment and Urbanization, 12(1), pp. 197-202. DOI: 10.1177/095624780001200114.

Tong, T. (2010) 'From Colonialism to Modernism to Postcolonialism: The Case of Urban Agriculture in Lusaka, Zambia', Undercurrent: The Canadian Undergraduate Journal of Development Studies, 7(3), pp. 36-43.

Tostensen, A., I. Tvedten and M. Vaa (eds.) (2001) Associational Life in African Cities: Popular Responses to the Urban Crisis (Uppsala: Nordiska Afrikainstitutet).

UNDP (United Nations Development Programme) (1997) Governance for Sustainable Human Development (New York: UNDP).

UN-Habitat (United Nations Human Settlements Programme) (2016) Urbanization and Development: Emerging Futures. World Cities Report 2016 (Nairobi: UNHabitat).

UN-Habitat (2014) The State of African Cities 2014: Re-imagining Sustainable Urban Transitions (Nairobi: UN-Habitat).

UN-Habitat (2009) Global Report on Human Settlements 2009: Planning Sustainable Cities (London, UK: Earthscan).

UN-Habitat (2008) The State of African Cities 2008: A Framework for Addressing Urban Challenges in Africa (Nairobi: UN-Habitat).

UN-Habitat (2002) Global Campaign on Urban Governance: Concept Paper (2nd edition; Nairobi: UN-Habitat).

Wagah, G.G., G.M. Onyango and J.K. Kibwage (2010) 'Accessibility of Water Services in Kisumu Municipality, Kenya', Journal of Geography and Regional Planning, 2(5), pp. 114-125, http://www.academicjournals.org/journal/JGRP/article-abstract/ E9F $373 \mathrm{C}_{39648}$ (accessed on 20 April 2018).

Watson, V. (2009) 'Seeing from the South: Refocusing Urban Planning on the Globe's Central Urban Issues'. Urban Studies, 46(11), pp. 2259-2275, DOI: 10.1177/ 0042098009342598.

Weatherspoon, D.D. and T. Reardon (2003) 'The Rise of Supermarkets in Africa: Implications for Agrifood Systems and the Rural Poor', Development Policy Review, 21(3), pp. 333-355, DOI:10.1111/1467-7679.00214.

World Bank (2017) World Development Report 2017: Governance and the Law (Washington, DC: The World Bank), DOI: 10.1596/978-1-4648-0950-7.

World Bank (1994). Governance, The World Bank's Experience (Washington, DC: The World Bank).

World Bank (1992) Governance and Development (Washington, DC: The World Bank). World Bank (1989) Sub-Saharan Africa, From Crisis to Sustainable Growth, A Long Term Perspective Study (Washington, DC: The World Bank). 